\title{
Molecular systematics of the genus Senecio L. II: The origin of $S$. vulgaris $L$.
}

\author{
STEPHEN A. HARRIS \& RUTH INGRAM \\ Department of Biology and Preclinical Medicine, Sir Harold Mitchell Building, University of St Andrews, St Andrews, \\ Fife KY16 9TH, Scotland
}

The origin of Senecio vulgaris L. and the relationship of its two subspecies, ssp. vulgaris and ssp. denticulatus (O. F. Muell.) P. D. Sell, are examined using nuclear ribosomal and chloroplast DNA analyses. No evidence was found to support either an allopolyploid or an autopolyploid origin of $S$. vulgaris, although it would appear that $S$. vernalis Waldst. \& Kit. is not one of the progenitor taxa. Two results of particular interest were found: (i) the apparent identity of the chloroplast genomes of $S$. vulgaris ssp. vulgaris and $S$. squalidus $\mathrm{L}$. and (ii) the divergence of the chloroplast genomes of ssp. vulgaris and Ainsdale ssp. denticulatus by at least eight site mutations. These results are discussed in the light of evidence derived from morphological, cytological and allozyme studies.

Keywords: Asteraceae, molecular variation, Senecio vulgaris ssp. vulgaris, S. vulgaris ssp. denticulatus.

\section{Introduction}

Senecio vulgaris L., the common groundsel, is one of the most widespread annual/ephemeral species in Britain. Taxonomically two subspecies are recognized, which differ ecologically. Senecio vulgaris ssp. vulgaris is the common weedy groundsel associated with disturbed sites, whilst ssp. denticulatus (O. F. Muell.) P. D. Sell is rare in Britain, being confined to a few coastal sites, where it grows on sand dunes (Lancashire and Channel Islands). This subspecies is a winter annual. Kadereit (1984a) discusses the life-history and germination pattern of ssp. denticulatus and states that this subspecies becomes a montane element in the Mediterranean. Allen (1967) lists the coastal sites in Europe where the subspecies occurs. Early records of ssp. denticulatus (Allen, 1967; Perring \& Sell, 1968; Crisp, 1972) from other coastal sites in the British Isles (Devon, Cornwall, Cheshire and the Isle of Man) have not been confirmed in recent years (Ashton, 1990). This may be due to extinction of the subspecies at these sites or the early confusion surrounding the nomenclature of the intraspecific ranks of $S$. vulgaris (Allen, 1967).

Morphologically, Senecio vulgaris ssp. denticulatus is distinguished from ssp. vulgaris by the possession of short ray florets, a densely arachinoid indumentum and characteristically spathulate leaf shape (Allen, 1967; Kadereit, 1984b).

Within Senecio vulgaris ssp. vulgaris, two varieties are recognized: var. vulgaris, the more frequent nonradiate variety and var. hibernicus, an inland radiate variety which has increased in frequency in recent years. Isozyme analysis indicates that the latter variety has originated through introgression from $S$. squalidus, following the introduction of $S$. squalidus in the seventeenth century and its more recent spread and naturalization (Abbott et al., 1991).

There are thus three intraspecific taxa recognized in Senecio vulgaris, all of which are tetraploid $(2 n=4 x=40)$. Kadereit $(1984 b)$ suggested that $S$. vulgaris ssp. denticulatus is an autopolyploid of fairly recent origin with $S$. vernalis $(2 n=2 x=20)$ as its parent. Kadereit also suggested that ssp. denticulatus is an ancestoral form of ssp. vulgaris through selection for an ephemeral life-history as an agricultural weed. An alternative suggestion, based on cytological studies of chromosome pairing in species-species hybrids was put forward by Weir \& Ingram (1980). They suggested an allopolyploid origin for $S$. vulgaris between $S$. squalidus, or a taxon related to it, and a second unidentified taxon. These two suggestions need not be mutually exclusive because there can be no clear division between autopolyploidy and allopolyploidy, 
and the nature of the control of chromosome pairing in polyploids of this group is complex (Ingram \& Noltie, 1987, 1989).

Recently polyploid speciation has been analysed using molecular techniques. Both the nuclear and chloroplast genomes have been successfully used. The nuclear genome is inherited biparentally and tandemly arranged ribosomal sequences (rDNA) have proved very useful (Jorgensen \& Cluster, 1988). Ribosomal RNA genes have proved useful in confirming hybridity in Claytonia (Doyle \& Doyle, 1988). Similar examples are found in Tripsacum andersonii (Talbert et al., 1990) and the Saxifragaceae (Doyle et al., 1985). In each case the supposed hybrid had the additive rDNA patterns of the two putative parents.

The Angiosperm chloroplast genome ( $c p D N A)$ is a small circular molecule which is usually inherited uniparentally through the maternal parent (Palmer et al., 1988; Harris \& Ingram, 1991b). Chloroplast DNA has been used to address questions of both allopolyploid and autopolyploid speciation, although allopolyploid speciation is the most studied of these two modes. Studies of allopolyploid speciation using cpDNA markers have been made, for example, in Papaver (Milo et al., 1988), Senecio cambrensis (Harris \& Ingram, 1991a), Tragopogon (Soltis \& Soltis, 1989) and Oryza (Dally \& Second, 1990). Autopolyploid speciation has been successfully studied in Heuchera grossulariifolia (Wolf et al., 1990) and H. micranthera (Soltis et al., 1989).

The aims of the present investigation were: (i) to determine the possible origin of Senecio vulgaris s.l. using cpDNA and rDNA markers; and (ii) to analyse the relationship between $S$. vulgaris ssp. vulgaris and ssp. denticulatus using rDNA and cpDNA markers. In pursuit of these aims the rDNA and cpDNA genomes of representatives from all subspecific taxa of $S$. vulgaris, and of $S$. squalidus and $S$. vernalis have been analysed. As a control S. cambrensis $(2 n=6 x=60)$, the allohexaploid hybrid of $S$. vulgaris and $S$. squalidus, has been included and the genomes of $S$. jacobaea and $S$. paludosus have been used as outgroups.

\section{Materials and methods}

\section{Plant material}

Achenes from single individuals of Senecio cambrensis Rosser, S. jacobaea L., S. paludosus L., S. squalidus L., S. vernalis Waldst. \& Kit., S. vulgaris L. ssp. denticulatus (O. F. Muell.) P. D. Sell, S. vulgaris L. ssp. vulgaris var. hibernicus Syme and $S$. vulgaris $L$. ssp. vulgaris var. vulgaris, representing 19 accessions (Table 1) were grown as stated in Harris \& Ingram (1991a). All of the taxa, except $S$. paludosus (Section Doria) have been variously placed in either Section Jacobaea or Section Senecio (Chater \& Walters, 1976; Alexander, 1979).

\section{DNA extraction and molecular methods}

DNA extraction and molecular methods are given in Harris \& Ingram (1991a). In the cpDNA analysis a total of 11 restriction enzymes were used; one tetranucleotide cutting enzyme (HaeIII), 10 hexanucleotide cutting enzymes (BamHI, BglII, EcoRI, EcoRV, HinDIII, KpnI, PstI, SacI, XhoI) and one heptanucleotide cutting enzyme (BstEII). In the rDNA survey only three enzymes were used (BamHI, EcoRI, EcoRV).

\section{Probe characteristics}

Cloned Lactuca sativa cpDNA fragments (Jansen \& Palmer, 1987) were used either singly (C1, C2, C4, C6, $\mathrm{C} 7, \mathrm{C} 9, \mathrm{C} 15)$ or as a mixture (C5a-C5c; $\mathrm{C} 10-\mathrm{C} 11-\mathrm{C} 12$; $\mathrm{C} 13-\mathrm{C} 14)$. These probes sampled approximately 80 per cent of the Senecio chloroplast genome.

A cloned nuclear ribosomal DNA repeat from Triticum aestivum 'Chinese Spring' was used to locate ribosomal sequences in the Senecio nuclear genome. The probe, pTA71, is a complete rDNA repeat of 9.1 kb cloned into an EcoRI site of pUC19 (Gerlach \& Bedbrook, 1979). In addition two rDNA clones from Taraxacum were used (King \& Schaal, 1990). pTEE3 is a $3.9 \mathrm{~kb}$ EcoRI fragment which contains the coding region of the rDNA repeat. pTEE5 is a $5.3 \mathrm{~kb}$ EcoRI fragment which contains the majority of the intergenic spacer and part of the $18 \mathrm{~S}$ rDNA gene.

\section{Data analysis}

Sequence divergence estimates for cpDNA were obtained by a maximum likelihood method (Nei, 1987; eq. 5.50 and 5.51) using only the mutations which could positively be inferred as site mutations. Other mutations were ignored in these estimates, which therefore underestimates the degree of divergence. Phylogenetic analysis was conducted only on site mutations using the branch and bound Wagner parsiomony program PENNY in the package PHYLIP (Felsenstein, 1985). The branch and bound option is guaranteed to find all the most parsimonious trees. Restriction site mutations were polarized using the outgroup $S$. paludosus (Section Doria).

The data from the rDNA analysis were treated rather differently due to the large degree of intertaxon variation and the difficulty of assigning length or site 
Table 1 Locations of the Senecio taxa studied

\begin{tabular}{|c|c|c|c|c|c|}
\hline Taxon & Location & $\begin{array}{l}\text { Grid } \\
\text { reference }\end{array}$ & $\begin{array}{l}\text { Number of } \\
\text { individuals }\end{array}$ & Source & Code \\
\hline \multicolumn{6}{|l|}{ Section Senecio } \\
\hline \multirow{4}{*}{$\begin{array}{l}\text { S. vulgaris ssp. vulgaris var. } \\
\text { vulgaris }\end{array}$} & Migvie, Aberdeenshire (M) & NJ437068 & 1 & RJA & $\mathrm{V} 1$ \\
\hline & York $(\mathrm{P})$ & SE590510 & 1 & PA & $\mathrm{V} 2$ \\
\hline & Mochdre, Wales (P) & SH822781 & 1 & PA & V3 \\
\hline & Salamander Street, Edinburgh (P) & NT276763 & 1 & PA & V4 \\
\hline \multirow{4}{*}{$\begin{array}{l}\text { S. vulgaris ssp. vulgaris var } \\
\text { hibernicus }\end{array}$} & Mochdre, Wales & SH822781 & 1 & PA & H1 \\
\hline & Brymbo, Wales & SJ296539 & 1 & PA & $\mathrm{H} 2$ \\
\hline & Salamander Street, Edinburgh & NT276763 & 1 & PA & $\mathrm{H} 3$ \\
\hline & York & SE590510 & 1 & RJA & $\mathrm{H} 4$ \\
\hline S. vulgaris ssp. denticulatus & Ainsdale, Lancashire & SD295124 & 1 & PA & D1 \\
\hline \multirow[t]{5}{*}{ S. squalidus } & Salamander Street, Edinburgh & NT276763 & 1 & PA & S1 \\
\hline & Brymbo, Wales & SJ296539 & 1 & PA & S2 \\
\hline & Stoke & SP360780 & 1 & PA & S3 \\
\hline & York & SE590510 & 1 & PA & S4 \\
\hline & Sheffield & SK350870 & 1 & PA & S5 \\
\hline \multirow[t]{2}{*}{ S. cambrensis } & Salamander Street, Edinburgh & NT276763 & 1 & SAH & $\mathrm{C} 1$ \\
\hline & $\begin{array}{l}\text { Brymbo, Wales } \\
\text { Schlusserlacker Weide, }\end{array}$ & SJ296539 & 1 & PA & $\mathrm{C} 2$ \\
\hline S. vernalis & $\begin{array}{l}\text { Eppelheim near Heildelberg, } \\
\text { Germany }\end{array}$ & - & 1 & PA & Ve1 \\
\hline \multirow{2}{*}{$\begin{array}{c}\text { S. jacobaea } \\
\text { Section Doria } \\
\text { S. paludosus }\end{array}$} & Tentsmuir Forest, Fife & NO499241 & 1 & $\mathrm{SAH}$ & $\mathrm{J} 1$ \\
\hline & British material [SMW 232-72W] & - & 1 & $\mathrm{CaBG}$ & P1 \\
\hline
\end{tabular}

Monomorphic $(\mathrm{M})$ and polymorphic $(\mathrm{P}) S$. vulgaris ssp. vulgaris populations.

CaBG - Cambridge University Botanic Gardens, PA - Paul Ashton, RJA - Richard Abbott, SAH - Stephen Harris.

mutations to the differences. Shared fragment patterns were scored and a measure of phenotype similarity calculated (Nei, 1987; eq. 5.53) before the values were clustered using an Unweighted Pair Mean Group Analysis (UPGMA; Sneath \& Sokal, 1973).

\section{Results}

\section{Ribosomal DNA variation}

Twenty-two rDNA phenotypes were found using three enzymes (BamHI, EcoRI, EcoRV) within and between Senecio vulgaris ssp. vulgaris s.l., S. vulgaris ssp. denticulatus, S. squalidus, S. cambrensis, and S. vernalis. The rDNA variation encountered within Senecio vulgaris ssp. vulgaris s.l., S. squalidus and S. cambrensis has been described in Harris \& Ingram (1991a).

Analysis of the patterns on the basis of shared fragments, followed by clustering using UPGMA (Fig. 1) clearly shows that all of the taxa could be distinguished with two or more of the enzymes used. The nature of this variation, either as the result of length or site mutations, could not be determined. However, it is clear that the rDNA phenotypes found in $S$. vulgaris ssp. denticulatus are quite different from any of the intraspecific variants which were encountered in $S$. vulgaris ssp. vulgaris s.l. (Fig. 2).

\section{Chloroplast DNA variation}

An average of 387 restriction fragments were produced by the 11 enzymes used in this study, which sampled approximately 2211 bp or 1.5 per cent of the Senecio chloroplast genome (assuming that the cpDNA is $150 \mathrm{~kb}$ in length; Jansen \& Palmer, 1987). Sixty-four site mutations and one length mutation were inferred from the data (Table 2). In addition a further 35 mutations were found which could not be explained as either length or site mutations (Table 2), these mutations were excluded from further data analysis. Two addtional site mutations were also excluded from the dataset for further analysis because they were either 
(a)

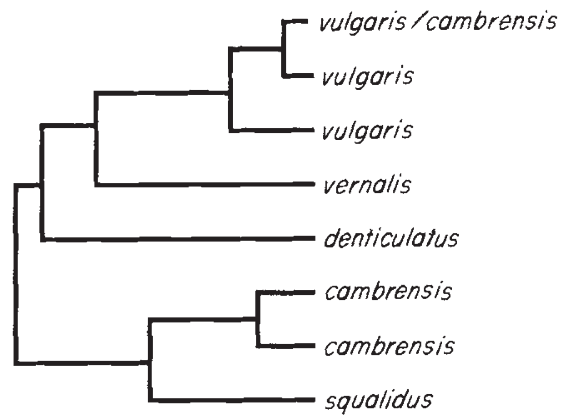

(b)
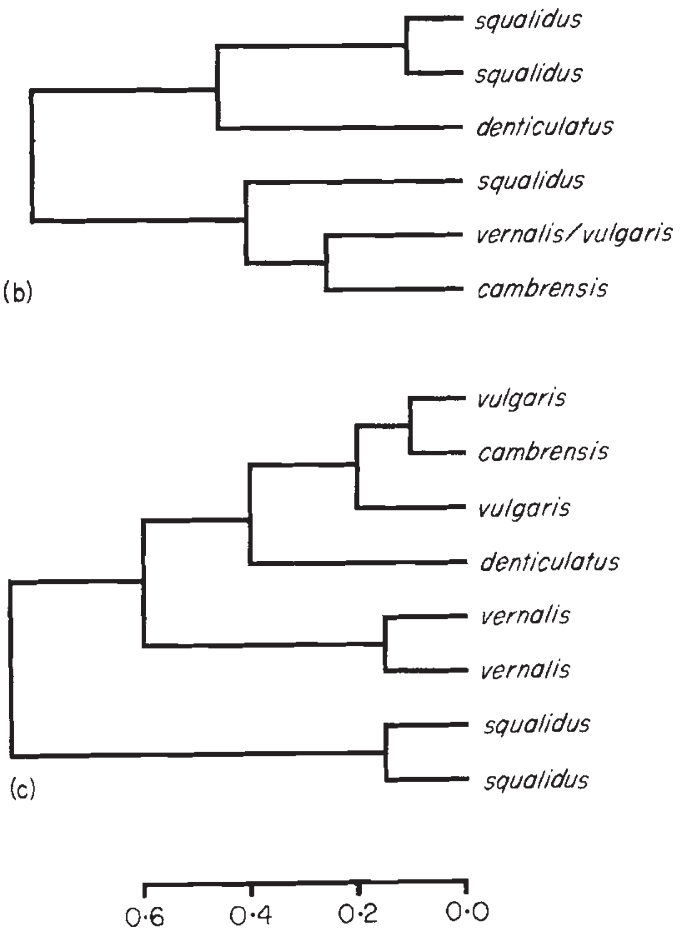

Fig. 1 UPGMA phenogram of the rDNA phenotypes identified in the genus Senecio. (a) BamHI, (b) EcoRI and (c) EcoRV.

correlated with herbicide resistance in Senecio (mutation No. 58; Bleyden, 1988) or unique to one $S$. squalidus accession (mutation No. 49).

Sequence divergence estimates calculated from the site mutation data (Table 3, Fig. 3) show that betweenspecies divergence estimates range from 0.000 per cent (between $S$. squalidus and $S$. vulgaris ssp. vulgaris) to 1.352 per cent (between $S$. vulgaris ssp. vulgaris and $S$. paludosus). These are minimum estimates because several mutations were excluded. In addition intraspecific variation was encountered between the accessions of $S$. squalidus, $S$. vulgaris ssp. vulgaris s.l. and $S$. cambrensis. The only length mutation was encountered in a Welsh population of $S$. cambrensis (Harris \& Ingram, 1991a).

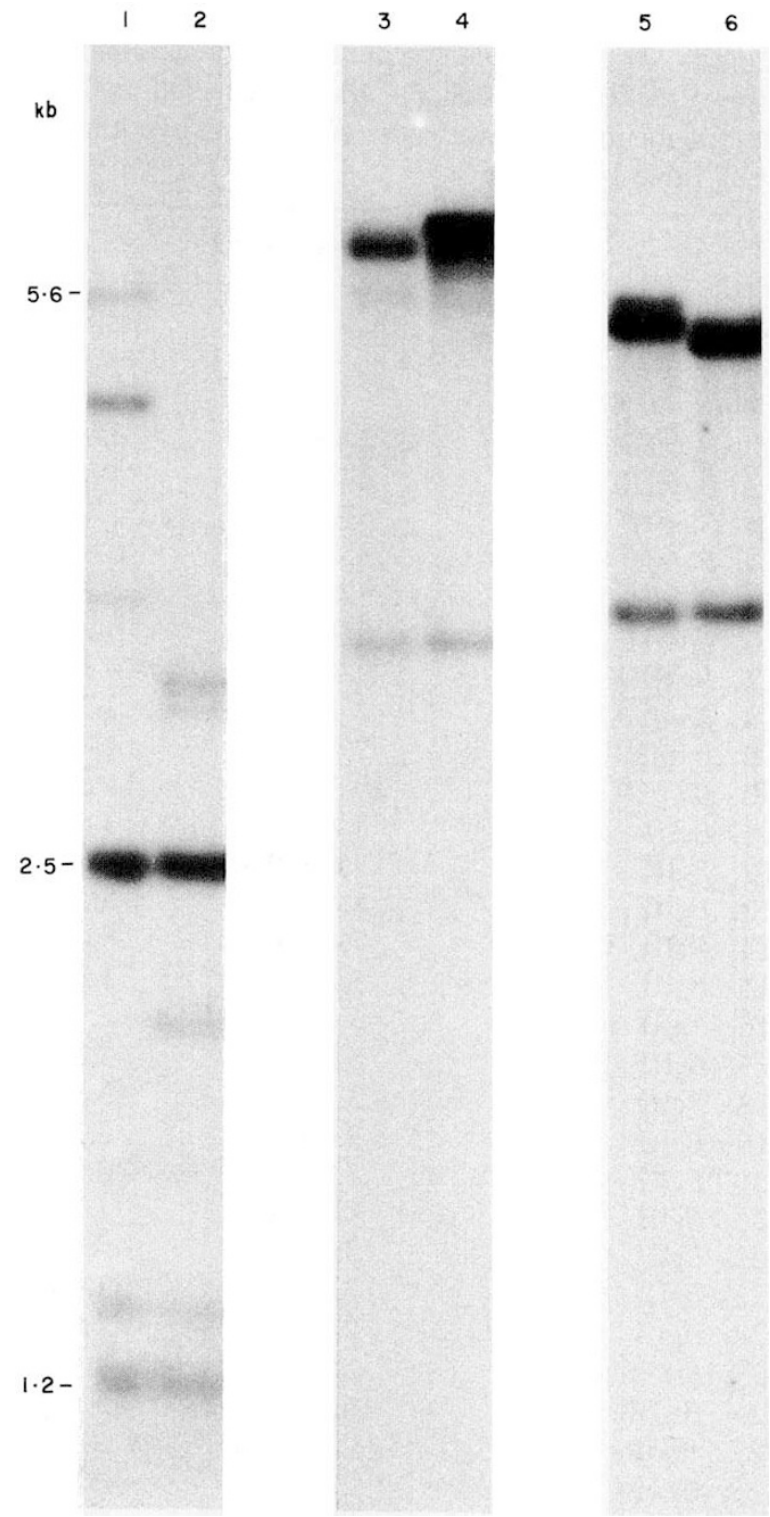

Fig. 2 Autoradiogram of Senecio vulgaris ssp. vulgaris (lanes $1,3,5$ ) and $S$. vulgaris ssp. denticulatus (lanes 2, 4, 6) probed with Taraxacum ribosomal DNA probe pTEE5. A. BamHI, B. EcoRI and C. EcoRV.

Thirty-four of the 62 restriction sites used in the phylogenetic analysis were autapomorphic and 28 were synapomorphic, with respect to the $S$. paludosus outgroup. Wagner parsimony analysis resulted in three most parsimonious trees (each of 62 steps) to explain the data (Fig. 4). The difference between the trees was due to the non-resolution of the trichotomy between the 'composite' taxon ( $S$. vulgaris ssp. vulgaris, $S$. cambrensis and $S$. squalidus), S. vulgaris ssp. denticulatus and $S$. vernalis. This trichotomy is supported by 15 synapomorphies. 
Table 2 Restriction fragment changes observed between taxa of Senecio.

Restriction site mutations, length mutations and unidentified mutations. The outgroup, S. paludosus has characters states in column 0 . Figures in parentheses indicate fragments which were not detected, but hypothesized to be present. Taxa coding as Table 1

\begin{tabular}{|c|c|c|c|c|}
\hline \multirow[b]{2}{*}{ Enzyme } & \multirow[b]{2}{*}{ Probe } & \multicolumn{2}{|l|}{ Character states } & \multirow[b]{2}{*}{ Taxa } \\
\hline & & 0 & 1 & \\
\hline \multicolumn{5}{|c|}{ Restriction site mutations } \\
\hline 1. BamHI & $\mathrm{C} 2$ & $2.4+0.7$ & 3.0 & All except J1 \\
\hline 2. BamHI & $\mathrm{C} 4$ & 24.8 & $19.1+4.3$ & All except J1 \\
\hline 3. BamHI & C6 & 6.3 & $5.4+(0.7)$ & All \\
\hline 4. BamHI & C6 & $5.4+(0.6)$ & 6.0 & Ve1 \\
\hline 5. BamHI & $\mathrm{C} 6$ & 5.4 & $5.2+(0.2)$ & D1 \\
\hline 6. BamHI & C6 & 0.95 & $0.91+(0.04)$ & All \\
\hline 7. BamHI & C6 & 0.91 & $0.88+(0.03)$ & $\mathrm{J} 1$ \\
\hline 8. BamHI & $\mathrm{C} 9$ & 2.4 & $2.3+(0.1)$ & All \\
\hline 9. BamHI & $\mathrm{C} 9$ & 7.4 & $4.8+2.3$ & $\mathrm{~J} 1$ \\
\hline 10. BamHI & $\mathrm{C} 10-\mathrm{C} 12$ & 19.3 & $11.8+8.5$ & All \\
\hline 11. BgIII & $\mathrm{C} 2$ & 5.4 & $3.8+1.2$ & All except J1 \\
\hline 12. BgIII & $\mathrm{C} 4$ & $7.6+(0.4)$ & 8.0 & All except J1 \\
\hline 13. BgIII & $\mathrm{C} 5 \mathrm{ac}$ & 8.4 & $8.2+(0.2)$ & All except J1 \\
\hline 14. BgIII & $\mathrm{C} 5 \mathrm{ac}$ & $7.4+(0.6)$ & 8.0 & All except J1 \\
\hline 15. BgIII & C6 & $1.2+(0.1)$ & 1.3 & $\mathrm{~J} 1$ \\
\hline 16. BgIII & $\mathrm{C} 6$ & 3.0 & $2.9+(0.1)$ & $\mathrm{J} 1$ \\
\hline 17. BgIII & $\mathrm{C} 6$ & 3.0 & $2.8+(0.2)$ & $\mathrm{D} 1$ \\
\hline 18. BgIII & $\mathrm{C} 6$ & $3.1+(0.4)$ & 3.5 & Ve1 \\
\hline 19. BgIII & $\mathrm{C} 6$ & $3.0+(0.3)$ & 3.3 & Ve1 \\
\hline 20. BgIII & $\mathrm{C} 6$ & 3.3 & $3.0+(0.3)$ & All \\
\hline 21. BgIII & $\mathrm{C} 7$ & $1.6+(0.1)$ & 1.7 & D1 \\
\hline 22. BgIII & $\mathrm{C} 7$ & $3.0+(0.4)$ & 3.4 & Ve1 \\
\hline 23. BgIII & $\mathrm{C} 7$ & 2.8 & $1.6+1.3$ & All except J1 \\
\hline 24. BgIII & $\mathrm{C} 10-\mathrm{C} 12$ & 2.1 & $1.8+(0.3)$ & $\mathrm{J} 1$ \\
\hline 25. BstEII & $\mathrm{C} 1$ & 1.6 & $1.1+(0.5)$ & $\mathrm{J} 1$ \\
\hline 26. BstEII & $\mathrm{C} 4$ & $16.2+(1.3)$ & 17.5 & All \\
\hline 27. EcoRI & $\mathrm{C} 4$ & $2.1+(0.1)$ & 2.2 & $\mathrm{~J} 1$ \\
\hline 28. EcoRI & $\mathrm{C} 6$ & $2.0+1.7$ & 3.7 & All except J1 \\
\hline 29. EcoRI & $\mathrm{C} 7$ & $0.35+(0.06)$ & 0.41 & $\mathrm{~J} 1$ \\
\hline 30. EcoRI & C9 & 5.7 & $5.4+(0.3)$ & All \\
\hline 31. EcoRI & $\mathrm{C} 10-12$ & $3.0+(0.1)$ & 3.1 & D1 \\
\hline 32. EcoRI & C10-12 & 4.2 & $3.9+(0.3)$ & $\mathrm{J} 1$ \\
\hline 33. EcoRI & C10-12 & 2.0 & $1.9+(0.1)$ & $\mathrm{J} 1$ \\
\hline 34. EcoRI & $\mathrm{C} 15$ & 0.4 & $0.37+(0.03)$ & $\mathrm{J} 1$ \\
\hline 35. EcoRI & $\mathrm{C} 15$ & $2.6+(0.5)$ & 3.2 & $\mathrm{~J} 1$ \\
\hline 36. EcoRI & $\mathrm{C} 15$ & 2.0 & $1.4+(0.6)$ & $\mathrm{J} 1$ \\
\hline 37. EcoRV & $\mathrm{C} 2$ & $3.8+(0.3)$ & 4.1 & $\mathrm{~J} 1$ \\
\hline 38. EcoRV & $\mathrm{C} 5 \mathrm{ac}$ & $19.0+(3.4)$ & 22.4 & All \\
\hline 39. EcoRV & C6 & 1.6 & $1.4+(0.2)$ & $\mathrm{J} 1$ \\
\hline 40. EcoRV & C6 & $7.8+(0.9)$ & 8.7 & Ve1 \\
\hline 41. EcoRV & $\mathrm{C} 7$ & $4.6+(0.1)$ & 4.7 & D1 \\
\hline 42. EcoRV & $\mathrm{C} 7$ & 1.5 & $1.4+(0.1)$ & $\mathrm{J} 1$ \\
\hline 43. EcoRV & $\mathrm{C} 10-\mathrm{C} 12$ & $9.3+(1.0)$ & 10.3 & All \\
\hline 44. HaeIII & $\mathrm{C} 1$ & $10.9+(0.4)$ & 11.3 & All \\
\hline 45. HaeIII & $\mathrm{C} 5 \mathrm{ac}$ & $2.9+(0.1)$ & 3.0 & All \\
\hline 46. HaeIII & $\mathrm{C} 5 \mathrm{ac}$ & 2.4 & $2.1+(0.3)$ & All except J1 \\
\hline 47. HaeIII & $\mathrm{C} 6$ & 2.6 & $2.4+(0.2)$ & D1 \\
\hline 48. HaeIII & C6 & 2.6 & $2.1+(0.5)$ & $\mathrm{J} 1$ \\
\hline
\end{tabular}


Table 2 continued

\begin{tabular}{|c|c|c|c|c|}
\hline \multirow[b]{2}{*}{ Enzyme } & \multirow[b]{2}{*}{ Probe } & \multicolumn{2}{|c|}{ Character states } & \multirow[b]{2}{*}{ Taxa } \\
\hline & & 0 & 1 & \\
\hline 49. HaeIII & C6 & 2.3 & $2.1+(0.2)$ & S5 \\
\hline 50. HaeIII & C7 & 0.8 & $0.6+(0.2)$ & $\mathrm{J} 1$ \\
\hline 51. HaeIII & $\mathrm{C} 9$ & $1.4+(0.1)$ & 1.5 & All except J1 \\
\hline 52. HaeIII & C9 & $0.6+(0.2)$ & 0.8 & All except J1 \\
\hline 53. HaeIII & $\mathrm{C} 13-\mathrm{C} 14$ & $2.0+1.1$ & 3.1 & All except J1 \\
\hline 54. HaeIII & $\mathrm{C} 13-\mathrm{C} 14$ & 2.7 & $1.6+1.1$ & All except $\mathrm{J} 1$ \\
\hline 55. HaeIII & $\mathrm{C} 15$ & $1.6+(0.1)$ & 1.7 & All except J1 \\
\hline 56. HaeIII & $\mathrm{C} 15$ & 0.9 & $0.86+(0.04)$ & All except J1 \\
\hline 57. HinDIII & $\mathrm{C} 9$ & $3.2+(0.3)$ & 3.5 & $\mathrm{~J} 1$ \\
\hline 58. HinDIII & $\mathrm{C} 10-\mathrm{C} 12$ & 11.3 & $6.0+4.8$ & $\begin{array}{l}\text { All except } \\
\mathrm{C} 1, \mathrm{H} 2, \mathrm{~V} 4\end{array}$ \\
\hline 59. KpnI & $\mathrm{C} 9$ & $5.5+(0.2)$ & 5.7 & $\mathrm{D} 1$ \\
\hline 60. PstI & $\mathrm{C} 1$ & 2.9 & $2.8+(0.1)$ & All \\
\hline 61. $S a c \mathrm{I}$ & $\mathrm{C} 9$ & 4.0 & $3.6+(0.4)$ & All \\
\hline 62. SacI & C9 & $3.6+(1.0)$ & 4.6 & $\mathrm{~J} 1$ \\
\hline 63. XhoI & $\mathrm{C} 7$ & $3.2+(0.2)$ & 3.4 & $\mathrm{D} 1$ \\
\hline 64. Xhol & $\mathrm{C} 7$ & $3.2+(0.1)$ & 3.3 & $\mathrm{~J} 1$ \\
\hline \multicolumn{5}{|c|}{ Length mutation } \\
\hline 65. BamHI & C6 & 5.38 & 5.70 & $\mathrm{C} 2$ \\
\hline 66. BgIII & $\mathrm{C} 6$ & 2.95 & 3.31 & $\mathrm{C} 2$ \\
\hline 67. SacI & C6 & 3.11 & 3.50 & $\mathrm{C} 2$ \\
\hline \multicolumn{5}{|c|}{ Unidentified mutations } \\
\hline 68. BamHI & $\mathrm{C} 5 \mathrm{ac}$ & 25.3 & 33.6 & $\mathrm{~J} 1$ \\
\hline 69. BamHI & C6 & - & 5.7 & V1 \\
\hline 70. BgIII & $\mathrm{C} 7$ & 3.0 & - & $\mathrm{J} 1, \mathrm{Ve} 1$ \\
\hline 71. BstEII & $\mathrm{C} 4$ & - & 3.6 & $\begin{array}{l}\text { All except } \\
\text { C1, S5 }\end{array}$ \\
\hline 72. BstEII & $\mathrm{C} 4$ & 5.5 & - & All \\
\hline 73. EcoRI & $\mathrm{C} 4$ & - & $3.0,2.0,1.7$ & S5 \\
\hline 74. EcoRI & $\mathrm{C} 4$ & $3.0,1.7$ & - & All except V2 \\
\hline 75. EcoRI & C6 & 1.2 & - & $\begin{array}{l}\mathrm{C} 1, \mathrm{H} 2, \mathrm{~J} 1 \\
\mathrm{Ve} 1\end{array}$ \\
\hline 76. EcoRI & $\mathrm{C} 6$ & - & $2.5,2.1$ & S5 \\
\hline 77. EcoRI & C6 & $2.5,2.1$ & $2.0,1.7$ & All \\
\hline 78. EcoRI & C6 & $2.0,1.7$ & 2.5 & $\mathrm{~J} 1$ \\
\hline 79. EcoRI & C7 & - & $1.4,0.77$ & S3 \\
\hline 80. EcoRI & $\mathrm{C} 7$ & - & 1.4 & $\mathrm{H} 1$ \\
\hline 81. EcoRV & C6 & 3.3 & - & $\begin{array}{l}\mathrm{D} 1, \mathrm{H} 1, \mathrm{H} 2 \\
\mathrm{H} 4, \mathrm{~S} 2, \mathrm{~S} 3 \\
\mathrm{~V} 4\end{array}$ \\
\hline 82. HaeIII & $\mathrm{C} 4$ & $3.2,1.7,1.3$ & $3.0,1.4$ & All \\
\hline 83. HaeIII & $\mathrm{C} 4$ & $3.0,1.4$ & $3.4,3.1$ & $\mathrm{~J} 1$ \\
\hline 84. HaeIII & C5ac & - & 2.6 & $\mathrm{~J} 1$ \\
\hline 85. HaeIII & $\mathrm{C} 6$ & $2.1,1.5$ & 2.3 & All \\
\hline 86. HaeIII & $\mathrm{C} 6$ & 1.3 & - & $\mathrm{J} 1$ \\
\hline 87. HaeIII & $\mathrm{C} 10-\mathrm{C} 12$ & 2.7 & - & $\mathrm{D} 1, \mathrm{Ve} 1$ \\
\hline 88. HaeIII & C15 & - & 1.4 & $\begin{array}{l}\text { All except } \\
\mathrm{C} 1, \mathrm{~J} 1, \mathrm{~S} 5\end{array}$ \\
\hline 89. HinDIII & $\mathrm{C} 5 \mathrm{ac}$ & $6.8,3.3$ & $10.3,4.8,3.7$ & All \\
\hline 90. Hin DIII & $\mathrm{C} 5 \mathrm{ac}$ & - & 6.7 & $\mathrm{~J} 1$ \\
\hline 91. HinDIII & $\mathrm{C} 4$ & 3.3 & - & All \\
\hline 92. HinDIII & C6 & $\begin{array}{c}18.3,16.1, \\
8.1,7.4\end{array}$ & $17.1,7.6$ & All \\
\hline
\end{tabular}


Table 2 continued

\begin{tabular}{cllll}
\hline \multicolumn{3}{c}{ Character states } & \\
\cline { 3 - 4 } Enzyme & Probe & 0 & 1 & Taxa \\
\hline 93. HinDIII & C9 & $9.2,8.5,3.3$ & 3.2 & All \\
94. HinDIII & C10-C12 & $11.9,9.2$, & $11.3,7.1$ & All \\
95. SacI & C4 & $5.4,3.2$ & & \\
& & 1.4 & - & All except \\
96. SacI & C6 & 4.8 & - & D1, Ve1 \\
& & & & All except \\
97. SacI & C6 & - & & C1, J1, S1 \\
98. SacI & C6 & $5.5,3.3,1.9$, & $1.5,3.1$ & S5, V1 \\
& & 1.8 & & All \\
99. SacI & C6 & $3.1,1.4$ & $3.1,2.6$ & \\
100. SacI & C10-C12 & 8.7 & 6.9 & J1 \\
101. Xhol & C7 & 5.6 & - & All \\
102. Xhol & C7 & - & 2.3 & All except \\
& & & & H3, V2 \\
\hline
\end{tabular}

Table 3 Chloroplast DNA sequence divergence estimates (above diagonal) and standard errors (below diagonal) for various species of Senecio. The chloroplast DNAs of $S$. vulgaris ssp. vulgaris and $S$. squalidus are apparently identical and, therefore have a sequence divergence estimate of 0.000

\begin{tabular}{llllll}
\hline & vulgaris & paludosus & jacobaea & vernalis & denticulatus \\
\hline vulgaris & - & 0.00820 & 0.0107 & 0.0023 & 0.0021 \\
paludosus & 0.0032 & - & 0.0103 & 0.0114 & 0.0135 \\
jacobaea & 0.0016 & 0.0008 & - & 0.0105 & 0.0115 \\
vernalis & 0.0007 & 0.0017 & 0.0016 & - & 0.0038 \\
denticulatus & 0.0007 & 0.0019 & 0.0014 & 0.0009 & - \\
\hline
\end{tabular}

This tree highlights two observations which are of particular interest: (i) the apparent identity of ssp. vulgaris and $S$. squalidus cpDNAs and (ii) the separation of the cpDNAs of ssp. vulgaris and Ainsdale ssp. denticulatus by at least eight site mutations.

\section{Discussion}

Two major observations may be made from the nuclear rDNA and cpDNA data in this study: (i) the rDNAs of Senecio squalidus and $S$. vulgaris ssp. vulgaris s.l. are clearly very different, but their cpDNAs are apparently inseparable, and (ii) S. vulgaris ssp. vulgaris and Ainsdale ssp. denticulatus have very divergent cpDNAs and rDNAs.

The range of minimum cpDNA sequence divergence estimates within the genus Senecio, 0.000-1.352 per cent (mean 0.842) are towards the upper end of the range found in other studies: e.g. Clarkia Section Peripetasma, 0.17-1.50 per cent (Sytsma \& Gottlieb, 1986); Oncidium, 0.14-2.77 per cent (Chase \& Palmer, 1989); Pisum, 0.10-0.81 per cent (Palmer et al., 1985). These represent minimum estimates for the genus because not all of the mutations scored in this study were used and secondly, the sample represents a very limited selection from this large and very diverse genus (Jeffrey et al., 1977; Jeffrey, 1978).

\section{The origin of Senecio vulgaris s.l.}

Kadereit (1984b) proposed that Senecio vulgaris ssp. vulgaris was the autopolyploid derivative of $S$. vernalis via $S$. vulgaris ssp. denticulatus. If these events were of recent occurrence then one would expect that the nuclear and organelle genomes of all three taxa would be very similar. All of the enzymes studied, except 


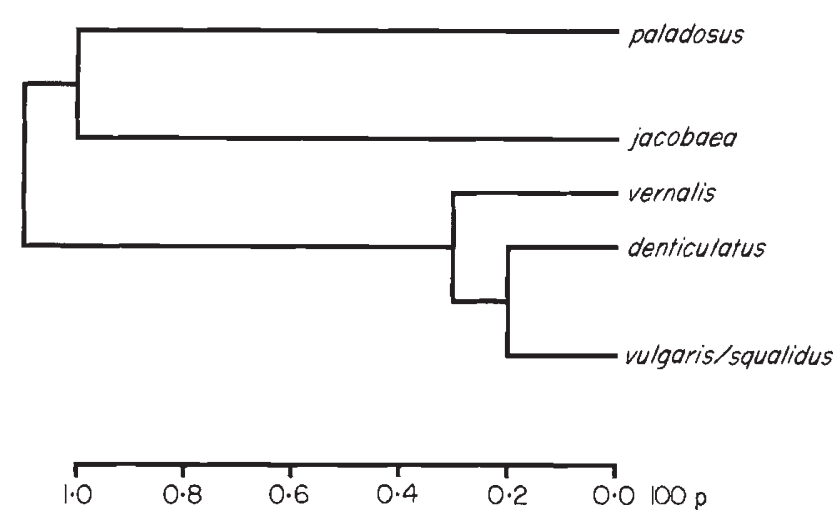

Fig. 3 UPGMA phenogram of chloroplast DNA divergence estimates $(100 \mathrm{p}$ ) based on those changes which could be ascribed to site mutations.

EcoRI, allowed the nuclear rDNA of all three taxa to be distinguished. In the case of EcoRI, this enzyme does not distinguish $S$. vernalis and $S$. vulgaris ssp. vulgaris rDNA. Similarly the cpDNA data allows each of the taxa to be distinguished, although the absence of synapomorphies between any two of the three taxa did not allow resolution of the three taxon trichotomy. Clearly the species are closely related compared to either S. jacobaea or S. paludosus in the cpDNA analysis and $S$. squalidus in the rDNA analysis.

Weir \& Ingram (1980) have proposed an allopolyploid origin of $S$. vulgaris, with half the tetraploid genome homeologous to $S$. squalidus. In this case one would expect $S$. vulgaris ssp. vulgaris s.l. to carry the cpDNA of the maternal parent and have an additive rDNA phenotype between the $S$. squalidus and an unknown Senecio species. Comparison of the rDNA phenotypes reveal no $S$. squalidus fragments in $S$. vulgaris ssp. vulgaris, other than the fragments common to all taxa, while the chloroplast DNA analysis reveals that $S$. vulgaris ssp. vulgaris and $S$. squalidus have identical cpDNA profiles. One interpretation of this data is that $S$. squalidus is the maternal parent of $S$. vulgaris spp. vulgaris, but this is unlikely given the evidence from the nuclear genome which does not indicate additive rDNA profiles.

This analysis of the nuclear rDNA and cpDNA does not provide unequivocal support for either an autopolyploid or an allopolyploid origin of Senecio vulgaris ssp. vulgaris. However, the distinct nuclear and organelle genomes of $S$. vernalis do not support the suggestion that this taxon is a recent ancestor of $S$. vulgaris ssp. vulgaris. Thus we suggest that the progenitor(s) of $S$. vulgaris must be searched for among other species, particularly those which occur in the Mediterranean region (Kadereit, 1984b).

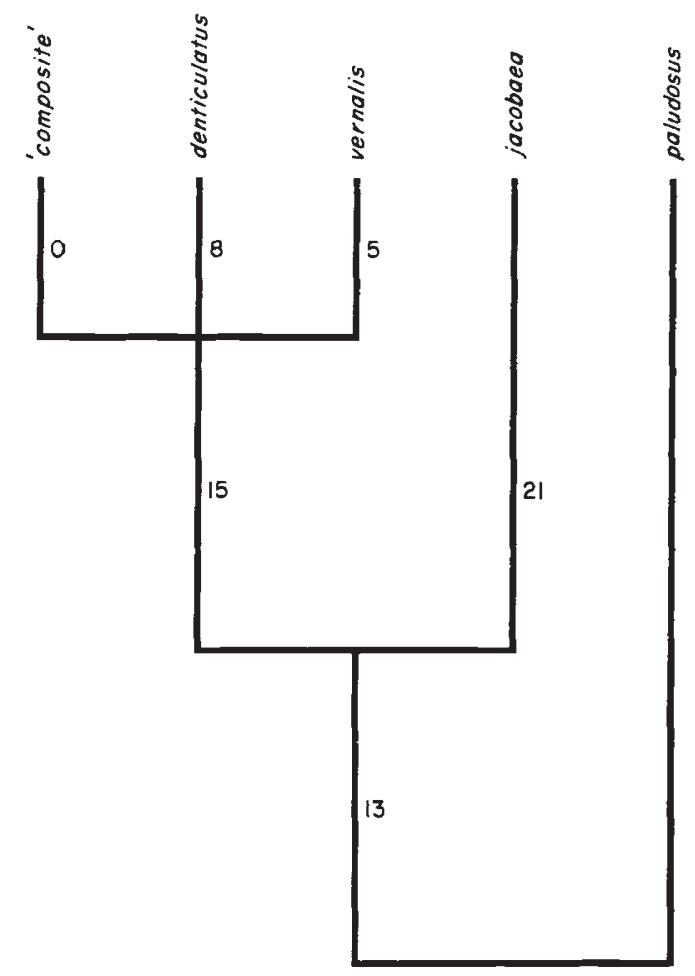

Fig. 4 Wagner parsimony tree of chloroplast DNA site mutations. The terminal branch referred to as 'composite' is Senecio vulgaris ssp. vulgaris, $S$. squalidus and $S$. cambrensis.

The status of Senecio vulgaris ssp. denticulatus

This study raises some questions about the status of Ainsdale Senecio vulgaris ssp. denticulatus as a subspecies of $S$. vulgaris. Both the nuclear and the cpDNA data indicate that ssp. vulgaris and ssp. denticulatus are different. The rDNA differences cannot be explained on the basis of simple length mutations in the intergenic spacer, rather, multiple mutations must be responsible for the pattern. Similarly the cpDNAs of ssp. vulgaris and Ainsdale ssp. denticulatus differ by at least eight site mutations. We would like to propose three possible explanations for the observed data: (i) localized hybridization and gene exchange has occurred, or is occurring, at the Ainsdale site between S. vulgaris s.l. and an unidentified Senecio species; (ii) multiple reciprocal allopolyploid origins of $S$. vulgaris may have occurred in the past leading to two lineages with differing cpDNAs; and (iii) the subspecific taxonomy of $S$ vulgaris is incorrect.

Taking each of the proposals separately. Localized gene exchange between ssp. denticulatus and a related species of Senecio may explain the result but the lack of spp. vulgaris rDNA fragments in Ainsdale ssp. denticulatus would tend to indicate that this is not the case, 
especially given that the rDNA fragment pattern changes between ssp. vulgaris and ssp. denticulatus are not of a simple nature. Support for the difference between ssp. Ainsdale denticulatus and ssp. denticulatus from other sites was found using $\beta$-Est loci (Ashton, 1990). In Ashton's study ssp. denticulatus from Jersey had an identical phenotype to ssp. vulgaris, whereas Ainsdale ssp. denticulatus possessed unique alleles at the $\beta$-EST- 1 and $\beta$-EST- 2 loci.

Multiple reciprocal allopolyploid origins of $S . v u l-$ garis between two diploid progenitors with different cpDNAs is possible but would require that the products of the two different crosses gave rise to two lineages (Murai \& Tsunewaki, 1984); either ssp. vulgaris or ssp. denticulatus. The difficulty with this hypothesis is that one would expect similar rDNA phenotypes.

Incorrect classification of ssp. denticulatus confounded by morphological convergence may explain the data. However, a change in status of ssp. denticulatus should not be made until more accessions from the entire range of ssp. denticulatus have been studied as the result found here may be peculiar to Ainsdale ssp. denticulatus.

An unexpected result, given the degree of cpDNA divergence between apparently conspecific taxa, was the similarity between the chloroplast genomes of $S$. squalidus and $S$. vulgaris ssp. vulgaris, although they could be distinguished on their rDNA phenotypes. This may imply a hybridization event following the introduction of $S$. squalidus to the British Isles, but further work is in progress on this problem.

These results reported in this paper add more data to the observations that molecular evidence may not always be concordant with evidence from other data sources. The results of such studies are of interest as they may provide evidence of interesting evolutionary pathways which are not observed when more traditional datasets are used. Some of the possible explanations for the lack of concordance between molecular data and other data sources have been reviewed by Sytsma (1990). Clearly one such result has been obtained in $S$. vulgaris s.l., but further evidence is required before more definite conclusions about the causes of the differences can be made.

\section{Acknowledgements}

We would like to thank J. D. Palmer (Indiana State University) for the gift of the Lactuca sativa cpDNA library, M. O'Dell (Cambridge Laboratory, John Innes Institute, Norwich) for the gift of the wheat ribosomal clone, pTA71 and L. King (Harvard University, MA) for the gift of the Taraxacum ribosomal clones, pTEE3 and pTEE5. Thanks are also due to Richard Abbott,
Paul Ashton, and the curator of the Cambridge Botanic Garden for collections of 'seed' material. This work was undertaken during the tenure of a NERC studentship to SAH.

\section{References}

AlEXANDER, J. C. M. 1979. The Mediterranean species of Senecio Sections Senecio and Delphinifolius. Notes. Roy. Bot. Gard. Edinb. 37, 387-428.

ALLEN, D. E. 1967. The taxonomy and nomenclature of the radiate variants of Senecio vulgaris L. Watsonia, 6 , 280-282.

ABBOTT, R. J., ASHTON, P. A. AND FORBES, D. G. 1992. Introgressive origin of the radiate groundsel, Senecio vulgaris var. hibernicus Syme: Aat-3 evidence. Heredity, 68, 425-435.

ASHTON, P. A. 1990. Multiple origins of Senecio cambrensis Rosser, and related evolutionary studies in British Senecio. PhD Thesis, University of St Andrews.

ChaSe, M. W. AND PAlmer, J. D. 1989. Chloroplast DNA sequences of Lilioid monocots: Resources, feasibility and an example from the Orchidaceae. Am. J. Bot. 76, 1720-1730.

CHATER, A. O. AND WAlters, s. M. 1976. Senecio L. In: (eds Tutin, T. G., Heywood, V. H., Burges, N. A., Moore, D. M., Valentine, D. H., Walters, S. M. and Webb, D. A. (eds) Flora Europaea Vol. 4. Cambridge University Press: Cambridge. pp. 191-205.

CRISP, P. 1972. Cytotaxonomic studies in the section Annui of Senecio. PhD Thesis, University of London.

DALLY, A. M. AND SECOND, G. 1990. Chloroplast DNA diversity in wild and cultivated species of rice (Genus Oryza, Section Oryza). Cladistic mutation and genetic distance analysis. Theor. Appl. Genet., 80, 209-222.

DOYLE, J. J. AND DOYLE, J. L. 1988. Natural interspecific hybridization in Eastern North American Claytonia. Am. J. Bot., 75, 1238-1246.

DOYLE, J. J., SOLTIS, D. E. AND SOLTIS, P. S. 1985. An intergeneric hybrid in the Saxifragaceae: evidence from ribosomal RNA genes. Am. J. Bot., 72, 1388-1391.

FELSENSTEIN, J. 1985. Confidence limits on phylogenies: an approach using the bootstrap. Evolution, 39, 783-791.

GERLACH, W. L. AND BEDBROOK, J. R. 1979. Cloning and characterisation of ribosomal RNA genes from wheat and barley. Nucl. Acids. Res., 7, 1869-1885.

HARRIS, S. A. AND INGRAM, R. 1991a. Molecular systematics of the genus Senecio L. I: Hybridization in a British polyploid complex. Heredity, 69, 1-10.

HARRIS, S. A. AND INGRAM, R. 1991b. Chloroplast DNA and biosystematics: The effects of intraspecific diversity and plastid transmission. Taxon, 40, 393-412.

INGRAM, R. AND NOLTIE, H. J. 1987. The control of chiasma frequency within a polyploid series of the genus Senecio (Compositae). Genetica, 72, 37-41.

INGRAM, R. AND NOLTIE, H. J. 1989. Early adjustment of patterns of metaphase association in the evolution of a polyploid species. Genetica, 78, 21-25. 
JANSEN, R. K. AND PALMER, J. D. 1987. Chloroplast DNA from lettuce and Barnadesia (Asteraceae): structure, gene localisation and characterisation of a large inversion. Curr. Genet., 11, 553-564.

JEFFREY, C. 1978. Generic and Sectional limits in Senecio (Compositae). II. Evaluation of some recent studies. Kew. Bull., 34, 49-58.

JEFFREY, C., HALLIDAY, P., WILMOT-DEAR, M. AND JANES, S. W. 1977. Generic and Sectional limits in Senecio (Compositae). I. Progress report. Kew. Bull., 32, 47-67.

JORGENSEN, R. A. AND CLUSTER, P. A. 1988. Modes and tempos in the evolution of nuclear ribosomal DNA: new characters for evolutionary studies and new markers for genetic and population studies. Ann. Miss. Bot. Gard., 75, 1238-1247.

KADEREIT, J. W. 1984a. Studies on the biology of Senecio vulgaris L. ssp. denticulatus (O. F. Muell.) P. D. Sell. New Phytol., 97, 681-689.

KADEREIT, J. W. 1984b. The origin of Senecio vulgaris (Asteraceae). Pl. Syst. Evol., 145, 135-153.

KING, L. M. AND SCHAAL, B. A. 1990. Genotypic variation within asexual lineages of Taraxacum officinale. Proc. Natl. Acad. Sci. U.S.A. 87, 998-1002.

MiLo, J., LEVY, A., LADIZINSKY, G. AND PALEVITCH, D. 1988. Phylogenetics and genetic studies in Papaver Section Oxytona: cytogenetics, isozyme analysis and chloroplast DNA variation. Theor. Appl. Genet., 75, 795-802.

MURAI, K. AND TSUNEWAKI, K. 1984. Intraspecific variation of chloroplast DNAs (ctDNAs) in Aegilops triuncialis and geographical distribution of cytoplasmic types. Jpn. J. Breed. (Suppl.), 34, 280-281.

NEI, M. 1987. Molecular Evolutionary Genetics. Columbia University Press, New York.
PALMER, J. D., JANSEN, R. K., MICHAELS, H. J., CHASE, M. W. AND MANHART, J. R. 1988. Chloroplast DNA variation and plant phylogeny. Ann. Miss. Bot. Gard., 75, 1180-1218.

PALMER, J. D., JORGENSEN, R. A. AND THOMPSON, W. F. 1985. Chloroplast DNA variation and evolution in Pisum: Patterns of change and phylogenetic analysis. Genetics, 109, 195-213.

PERRING, F. H. AND SELL, P. D. 1968. Critical Supplement to the Atlas of the British Flora. Nelson and Sons, London.

SNEATH, P. H. A. AND SOKAL, R. R. 1973. Numerical Taxonomy. Freeman, San Francisco.

SOLTIS, D. E. AND SOLTIS, P. S. 1989. Allopolyploid speciation in Tragopogon: insights from chloroplast DNA. Am. J. Bot., 76, 1119-1124.

SOLTIS, D. E., SOLTIS, P. S. AND NESS, B. D. 1989. Chloroplast DNA variation and multiple origins of autopolyploidy in Heuchera micranthera. Evol., 43, 650-656.

SYTSMA, K. J. 1990. DNA and morphology: Inference of plant phylogeny. Trend. Ecol. Evol., 5, 104-110.

SYTSMA, K. J. AND GotTlieb, L. D. 1986. Chloroplast DNA evolution and phylogenetic relationships in Clarkia Section Peripetasma (Onagraceae). Evolution, 40, 1248-1261.

TALBERT, L. E., DOEBLEY, J. F., LARSON, S. AND CHANDLER, V. L. 1990. Tripsacum andersonii is a natural hybrid involving Zea and Tripsacum: Molecular evidence. Am. J. Bot., 77, 722-726.

WEIR, J. AND INGRAM, R. 1980. Ray morphology and cytological investigations of Senecio cambrensis Rosser. New. Phytol., 86, 237-241.

wolf, P. G., SOLTIS, D. E. AND SOLTIS, P. S. 1990. Chloroplast DNA and allozymic variation in diploid and autotetraploid Heuchera grossulariifolia (Saxifragaceae). Am. J. Bot., 77, 232-244. 